\title{
Indicators Framework for Sustainable Urban Design
}

\author{
Andrea López Chao ${ }^{1, *(\mathbb{D}, \text { Amparo Casares Gallego }}{ }^{1}$, Vicente Lopez-Chao ${ }^{1}$ (i) \\ and Alberto Alvarellos 2 (D) \\ 1 School of Architecture, University of A Coruña, 15008 A Coruña, Spain; amparo.casares@udc.es (A.C.G.); \\ v.lchao@udc.es (V.L.-C.) \\ 2 RNASA-IMEDIR, Computer Science Faculty, University of A Coruna, 15071 A Coruña, Spain; \\ alberto.alvarellos@udc.es \\ * Correspondence: andrea.lopez.chao@udc.es
}

Received: 25 September 2020; Accepted: 20 October 2020; Published: 22 October 2020

\begin{abstract}
Climate change and sustainability have recently been object of study due to the impact on the planet and on human activity of the first and the benefits that could derive from the efficiency of the second. Particularly, urban environments are locations that represent a high percentage of emissions of gases, waste, resources use and so forth. However, they are places where great changes can be made, in an attempt to accomplish the urgent challenge to adapt to current and projected rates of climate change. Research has shown that a fruitful approach to urban sustainability is to describe indicators that measure the effectiveness of current processes of urban infrastructures, analyze areas in need of improvement and measure the effect of any actions taken. The significant feature of this research relies on its global approach, considering both major worldwide used and less widely-spread frameworks and the analysis of the 32 selected tools and guidelines, including over 2000 indicators. The result is a proposed structure of 14 categories and 48 indicators, easily applicable in urban areas, that tries to fulfill basic aspects to obtain a general diagnosis of the sustainable nature of the urban environment, which can serve as support to detect the strongest and weakest areas in terms of their sustainability.
\end{abstract}

Keywords: architecture; assessment; tool; indicators; sustainability; cities

\section{Introduction}

Climate change is one of the most important environmental issues of our time. This concern reflects the reality that not only climate change is sensitive to human activity but also that much of human activity is sensitive to climate change and that adapting to current and projected rates of climate change could be very challenging. Although both natural processes and human activities can cause climate change, recent global warming has been largely attributed to human activity. However, there are proven energy and infrastructure solutions that can be put into use as of today to provide a more sustainable development.

The conversion of Earth's land surface to urban uses is one of the most irreversible human impacts on the global biosphere and the environmental impacts of urban expansion are undeniable [1]. But cities are also places of great efficiency, innovation and can be, especially in dense cities, great places of energy savings, too, although such savings do not appear automatically—an effort to accomplish improvements in these matters is mandatory. As the United Nations stated, managing urban areas has become one of the most important development challenges of the 21st century.

Cities are responsible for a great part of our energy expenses and harmful greenhouse gases. According to UN-Habitat, cities consume $78 \%$ of the world's energy and produce more than $60 \%$ of greenhouse gas emissions and $68 \%$ of the world population is projected to live in urban areas 
by 2050 [2]. But they are also the places where great efficiencies can potentially be made in terms of sustainability, through careful management of urban development and optimized resource use efficiency [3].

This makes it necessary to understand the form and content of urbanization to implement a reduction of our footprint. Understanding the contribution of cities to climate change will help intervene at a local level. The right approach to delivering and maintaining transport, housing, energy, water and communication infrastructure is essential to create a strong and competitive economy and provide social services.

Sustainable urban infrastructure is an infrastructure that facilitates a place's progress towards the goal of sustainable living. Attention also needs to be paid to technological and government policy, which enables urban planning for sustainable initiatives. Challenges resulting from increasing population growth generate a need for sustainable infrastructure that is high performing, cost-effective, resource-efficient and environmentally friendly.

Research has shown that an accurate way to take a fruitful approach to urban sustainability is to describe the most appropriate indicators to measure the effectiveness of current processes of urban infrastructures, as well as to be able to measure the effect of taken actions and therefore develop qualitative and quantitative descriptors of urban environments. Urban sustainability indicators are greatly important instruments for assessing the performance of cities and they can be of major help to improve it.

Different public actions have been used during the past few decades to manage city infrastructures considering several aspects considered within urban sustainability, both at a micro and macro level. Governments at all levels are currently taking into account the concepts of sustainable and smart and developing programs that involve both notions towards a better quality of life for citizens while maintaining economic growth.

Since 2014, 34 Organization for Economic Cooperation and Development (OECD) countries have been trying to collect data about people's well-being several times a year. Comparisons have been made using different criteria, such as access to services, civic engagement, the environment, individual incomes, employment and education — with open data being made available to researchers and citizens.

In the same line of action, the UN Sustainable Development Goals (SDGs) were unanimously adopted by the 193 UN Member States in 2015. They are comprised of 17 Global Goals and 169 targets intended to balance the economic, social and environmental dimensions of sustainable development. The SDGs and associated targets, indicators and evaluation metrics represent an internationally accepted framework for the evaluation of sustainability at a global level.

Also, in Europe, certain organizations are trying to identify the best frameworks to evaluate urban sustainability, which we will go into detail later on.

It is of big importance to dispose of a framework that includes indicators which are not only useful per se because of the information they provide but also as easy to obtain and measure as possible and preferably publicly available.

During the past few years there has been a certain level of research on said indicators, mostly by world-wide organisms in charge of actions against climate change (UN, World Bank, etc.) but oftentimes centered in a certain aspect of urban planning (water, energy, green spaces, roads, ... ) or including a really wide, general range of topics. Different guides have been developed to support the achievement of the SDGs, yet the alignment between the SDG targets and indicators and the great number of individually focused frameworks developed to evaluate specific actions at small scale remains unclear [3].

It would be highly useful to dispose of a framework that summaries a series of indicators that provide information about different aspects of the city which can result in a proper global image of its sustainability state, with those indicators being easy to measure (they should be formulated so they can be easily incorporated into an on-going program of gathering statistics) and easy to made widely available for online public access. 
Our objective is to review the more relevant existent frameworks, models, assessments and so forth and if appropriate, define a new holistic assessment framework that can be applied both to new and existing settlements, to create more efficient urban settlements and improve existing ones with certain measures depending on the results obtained with the framework, as regional and city planners do not count yet on a valid, widely accepted tool that enables their better assessment concerning sustainable urban planning and cities/towns/regions/countries do not count on a tool that helps them measure and improve their urban aspects enabling them an easier reach of UN goals.

The goal of this research is to support current cities' transformation into sustainable smart cities of the future, through the measurement of certain aspects, the implementation of actions to improve them and the monitoring of the results over time. Ideally, with a model that could even be used to compare cities, carefully applied.

While this research could happen at different levels (continents, countries, regions, cities, small settlements ... ), we will be focusing cities, as they are considered by literature the most suitable as a self-sufficient spatial unit for showing redevelopment results [4] although the framework could easily be adapted to smaller settlements, bigger regions or even countries.

The proposed framework (whether it is an existing one or a new one) would fundamentally enable smart cities to strengthen their strategic planning efforts and measure their progress towards a more sustainable progress and reaching the UN SDGs, among others.

\section{Urban Sustainability and Sustainability Indicators}

Since the emergence of the term Sustainable Development [5], the appearance of tools and assessments that attempt to measure the level of sustainability of an urban system through indicators has been quite fruitful $(\mathrm{OECD}, 2014)$ and to date, there is a heterogeneous amount of options to assess sustainability in an urban context, taking into account different aspects: the geographical scope of the selected area of study, the main interest of study and so forth. However, not all the sustainability criteria are always contemplated by each assessment or even those included in each one have not been thoroughly analyzed. There are also tools that include an overwhelming number of indicators, which are not easy to measure or obtain and are not necessarily relevant in every case.

According to Kennedy et al. [6], a sustainable city can only be one for which the inflow of material and energy resources and the disposal of wastes, do not exceed the capacity of the city's surrounding environment. As stated before, research shows that sustainability depends on social, economic, environmental and governance factors, which can only be achieved through great effort from a holistic point of view.

With respect to cities, indicators are understood to provide a barometer of how various aspects and parts of a city are unfolding and performing. These trends are most often revealed by charting them as graphs or maps or inserted into models which enable a general view of the current situation or a future possibility [7].

To create a sustainable urban environment, it is necessary to measure, assess policies and measure again in order to check the effectiveness of the applied policies. Indicators are an effective tool to pursue this objective, as properly selected, they allow the measurement and comparison of any aspect.

The selection of appropriate indicators is the base of any relevant framework/tool and should also be the first step of databases. Every indicator should be selected to detect both the current state and measure the progress in meeting the objectives of sustainability understood in its broadest sense.

An indicator (understood as a measurement or a value that provides relevant information) should be, according to existing literature (p. 31) [8]:

- Specific (must clearly relate to outcomes)

- Measurable (implies that it must be a quantitative indicator).

- Usable (practical).

- Sensitive (must readily change as circumstances change). 
- Available (it must be relatively straightforward to collect the necessary data for the indicator).

- Cost-effective (it should not be a very expensive task to access the necessary data).

Concerning the aspects of sustainability, the three-pillar conception of sustainability (social, economic and environmental) has become widely represented [9]. The inclusion of the three initial pillars did not occur at the same time but as a result of needs that appeared as the notion of sustainability matured. However, we find it necessary to include a fourth aspect, governance, as it is key in the implementation, management and reporting processes of overall sustainability.

Therefore, the range of indicators when it comes to our field of work should cover environmental, economic, social and governance areas, as sustainability should be obtained in every aspect without neglecting any of them. The challenge appears when defining a compound of indicators that conform a tool which is easy to implement and worth the effort.

BREEAM (UK) is one of the first tools to be have been introduced in sustainability assessments focused on buildings. Ever since its appearance, various tools have been developed worldwide, as the case of LEED in the US, CASBEE in Japan, ECOCITY in Europe or HQE in France.

Different governmental and non-governmental scientific organizations, such as SDEWES center, financial institutions like the World Bank, resulting in frameworks, toolkits or guides such as Urban Sustainability Framework (The World Bank) or Reference Framework for European sustainable cities.

Some projects concerning sustainability and indicators have also been funded by the different EU programs or funds and developed obtaining key performance indicators and data collection procedures, such as CITYkeys, ECO-city and KITCASP. There are also initiatives of the European Union to implement sustainable, clean and efficient urban transport measures, as CIVITAS.

Certain studies that have compared some of those tools [3], while others have applied some of them to compare their results in a practical case and some studies have even compared the tools, set a new tool based on their criteria and applied it [4].

The significant feature of this paper relies on its global approach, considering both major world-wide used and less widely-spread frameworks. In this study, indicators were selected in first place on the basis of their frequency, based on the analyzed data, consisting of 32 indicator sets, 224 categories and 2.060 indicators and in second place taking into account the following criteria: objectivity (clear, easy to understand, precise and unambiguous); relevance, measurability and reproductivity (quantitative, systematic observable); validity; comparability; and accessibility (available databases, use of existing data), as we will go into detail throughout the article.

\section{Materials and Methods}

The criteria for inclusion in this systematic review were studies, frameworks, assessments, tools, that evaluated or considered sustainability indicators in environmental, social, economic, and/or governance aspects. Those included papers, books, reviews, theoretical comparisons and tools with certain level of relevance. Case studies or studies that implemented frameworks were not included in the final selection, even though they were taken into consideration in the initial selection, among proceedings and gray literature.

The development of different search strategies for the each used database (Scopus, Web of Science, ... ), gray literature in Google Scholar and research by relevant Organizations, allowed us to examine an extensive number of references and choose a significant amount that met our criteria for consequent analysis. We managed all references using Zotero desktop software.

Study selection consisted of two phases. The first phase included a brief review of all the titles and abstracts of all identified references in the consulted databases and the discard of all articles, tools, assessments and so forth, that did not meet the eligibility criteria. This phase also included the selection of several frameworks and most highly used worldwide tools to assess urban or buildings sustainability, as well as the review of gray literature which was not to be included as reference but could provide valuable information. 
The second phase consisted of an extensive analysis of every selected papers and tools/assessments and the extraction of the necessary data concerning indicators that would then be classified and analyzed.

The characteristics collected from the selected studies and assessment tools included the following: authors and year of publication in the case of papers, geographical scope, the objective of the study or assessment, indicator(s) evaluated, classification of the indicator(s) if existed (category, subcategory and others).

Considering the literature review done, the final selection consisted of 32 indicators sets, which we proceeded to analyze and classify.

Table 1 shows the list of the included sets and how they are structured into categories. This in-depth analysis of each tool allowed the identification of the structure of indicators contained in each set to evaluate the sustainability of an urban area. In our analysis, we took into account aspects such as the geographical scope of each set, its original classification into categories and subcategories and the description of each indicator.

Table 1. Frameworks, Assessment Tools and Guidelines object of study.

\begin{tabular}{|c|c|c|c|}
\hline $\mathbf{N}$ & $\begin{array}{c}\text { Framework/Assessment } \\
\text { Tool/Guideline }\end{array}$ & N. Categories & N. Indicators \\
\hline 1 & SDEWES & 7 & 35 \\
\hline 2 & $\begin{array}{l}\text { LEED v4 for Neighborhood } \\
\text { Development }\end{array}$ & 5 & 59 \\
\hline 3 & BREEAM Communities & 9 & 62 \\
\hline 4 & CITYKeys & 5 & 99 \\
\hline 5 & CIVITAS & 9 & 28 \\
\hline 6 & Ecocity & 5 & 186 \\
\hline 7 & Le Modele Indi-Ru 2005 & 5 & 73 \\
\hline 8 & KITCASP & 4 & 20 \\
\hline 9 & LB & 7 & 93 \\
\hline 10 & SMIS & 6 & 39 \\
\hline 11 & CGYM & 8 & 52 \\
\hline 12 & SEV & 7 & 44 \\
\hline 13 & $\mathrm{BCN}$ & 4 & 13 \\
\hline 14 & BIL & 12 & 34 \\
\hline 15 & VERDE & 6 & 42 \\
\hline 16 & DGNB & 6 & 63 \\
\hline 17 & HQE & 14 & 158 \\
\hline 18 & $\begin{array}{l}\text { White Paper on Sustainability of } \\
\text { Spanish Urban Planning }\end{array}$ & 7 & 154 \\
\hline 19 & European Smart Cities Ranking & 6 & 64 \\
\hline 20 & REPLICATE PROJECT & 7 & 56 \\
\hline 21 & Smart City PROFILES & 5 & 21 \\
\hline 22 & City Protocol & 9 & 190 \\
\hline 23 & $\begin{array}{l}\text { ISO } 37120 \text { Sustainable development of } \\
\text { communities }\end{array}$ & 17 & 100 \\
\hline 24 & $\begin{array}{c}\text { Reference framework for European } \\
\text { sustainable cities (RFSC) }\end{array}$ & 5 & 30 \\
\hline 25 & $\begin{array}{l}\text { Sustainability Tools And Targets for } \\
\text { the Urban Thematic Strategy project }\end{array}$ & 8 & 46 \\
\hline 26 & UN Habitat indicators & 5 & 42 \\
\hline 27 & $\begin{array}{l}\text { CASBEE for Urban Development } \\
\text { (CASBEE-UD) }\end{array}$ & 7 & 82 \\
\hline 28 & $\begin{array}{l}\text { Urban Sustainability Framework } \\
\text { (The World Bank) }\end{array}$ & 9 & 43 \\
\hline 29 & The bridge project & 3 & 28 \\
\hline 30 & CESBA tool: new buildings & 5 & 22 \\
\hline 31 & European green city index & 8 & 30 \\
\hline 32 & $\begin{array}{l}\text { System of indicators and conditions } \\
\text { for large and medium-sized cities }\end{array}$ & 4 & 52 \\
\hline Total & & 224 & 2060 \\
\hline
\end{tabular}


Before comparing the indicators used in each tool, it was necessary to define a common structure as each tool uses a different classification system and a distinct nomenclature. To solve this aspect, the first step was to create a two-level structure of categories and subcategories with their corresponding objective.

The method used to obtain this was a thorough review of the indicator's structures proposed in the existent literature and a frequency analysis for categories, subcategories and indicators of each tool selected for this study. It then appeared that generally, categories are defined in such a way that each can include a wide range of indicators with diverse objectives.

An important observation related to this is that many indicators and categories are closely related, which would make it possible for an indicator or subcategory to be considered under different categories or even under different aspects (environmental, social, economic or governance).

\section{Results}

The proposed structure of categories, subcategories and indicators is based on their frequency among the 32 indicator sets object of this study. Figure 1 shows the word frequency of the 2060 indicators contained in the 32 selected indicator sets.

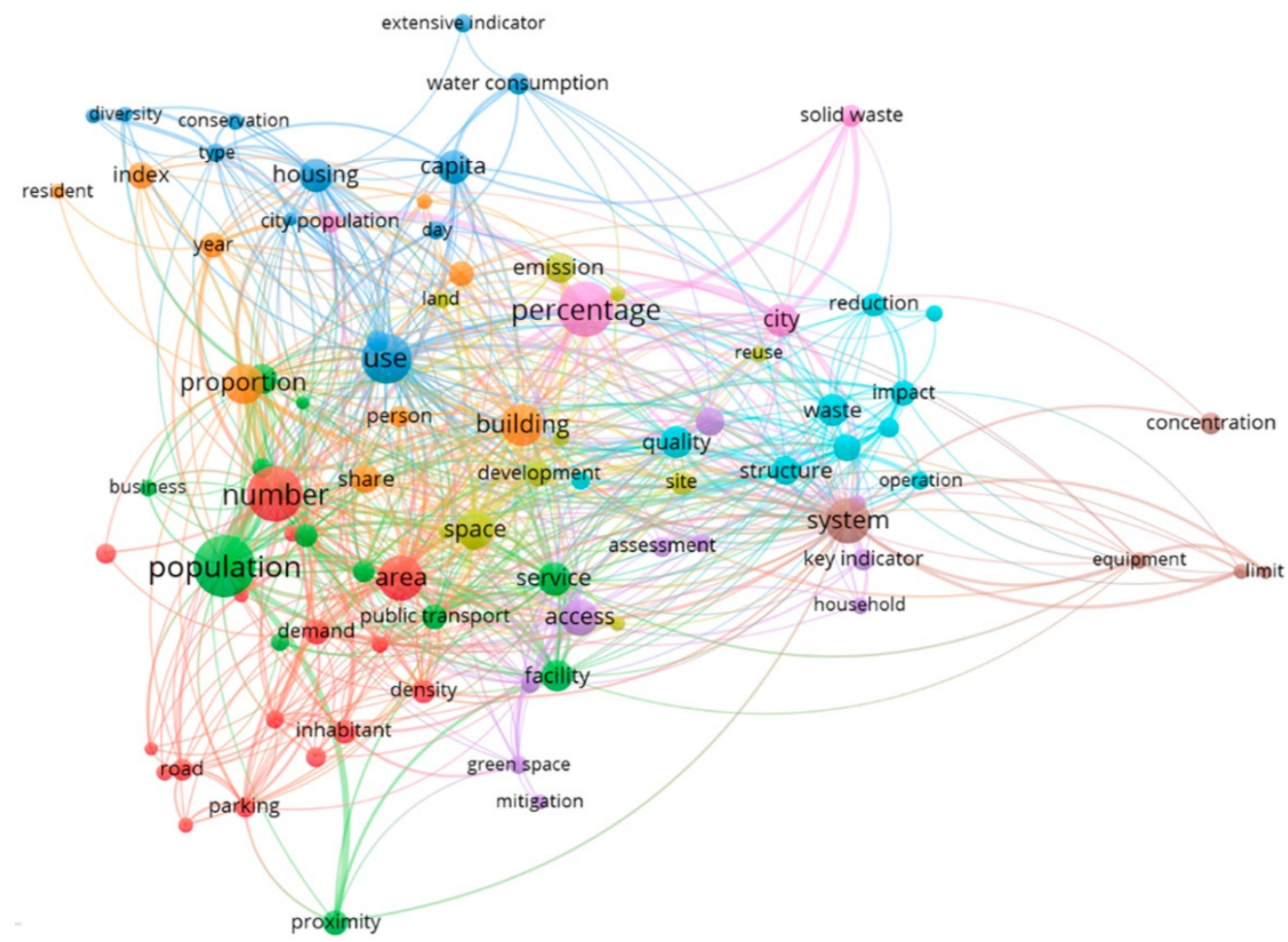

Figure 1. Visualization of the cluster network from the terms of sustainable urban indicators shown in Table 1 with a lower limit of co-occurrence of 7 .

Indicators were analyzed through a content analysis, which implies the codification of the meaning that allows its categorization, for which the analysis codes were established; the codification of the meaning, where a keyword is given to a part of the text and facilitate its identification; condensation of meaning, in which the meanings expressed in short formulations are summarized; and interpretation of meaning, in which the text is interpreted. As the meaning and the language are intermingled, this type of analysis allows attention to the linguistic features of an interview, being able to contribute to generate and verify the meaning of the statements, as well as to improve the precision of the questions in the interview [10].

Additionally, cluster analysis was used as support and verification of the correlations made in the previous analysis. This method, highly used in bibliometric environments, allows assigning 
relevance values to the terms based on the frequency of appearance in this case in the indicators, to generate categories. The method allows to set a minimum repetition value of the term to be entered in order to test different grouping results based on the relevance of the terms, so that, with a high number of frequencies, it would only include highly repeated terms and with a lower value of frequencies, low strength relationships are established.

Figure 1 is the result of concurrency 7 , which included 90 terms, repeated at least 7 times. It resulted in 10 groups, which provided support for the analysis of categorization of meaning carried out in the traditional way.

Color identifies different categories and the importance of the term is given by the size of the circle. The closeness between terms indicates a greater relationship between them. In this sense, the result confirms the need for an interdisciplinary vision of sustainability in urban environments and the difficulty of generating a measurement tool that encompasses issues that cover such diverse and specific topics.

Table 2 shows the results of the proposed category structure based on the analysis of the meaning of the indicators supported by the cluster analysis: environmental, social, governance, economy aspects, resulting in 14 categories:

Table 2. Proposed category structure.

\begin{tabular}{ccc}
\hline ESGE & Area & Category \\
\hline \multirow{2}{*}{ Environmental } & & Energy \\
Waste \\
& Resources & Water \\
& & Pollution \\
\cline { 2 - 3 } & Territory management & Mobility \& transport \\
& & Plan \& design \\
& Social & Site and land \\
\hline Social & & Social aspects \\
\hline \multirow{2}{*}{ Governance } & Governance & Management \\
& & City Planning \& Innovation \\
& & Transparency \\
\hline Economy & Economy & Local aspect \\
& & Labor \\
& & Finances \\
\hline
\end{tabular}

From the analysis carried out regarding aspects considered by each of the tools, we can conclude that all the frameworks include indicators related to the environment, around $80 \%$ consider the economic aspect, although in a generally low proportion, $90 \%$ consider the social aspect (this being the second aspect with the highest total number of indicators, after the environmental aspect) and only around $70 \%$ consider some aspect related to the government in some way. Figure 2 shows the number of indicators related to each aspect for each framework (the numbering of the frameworks corresponds to that shown in Table 1): 


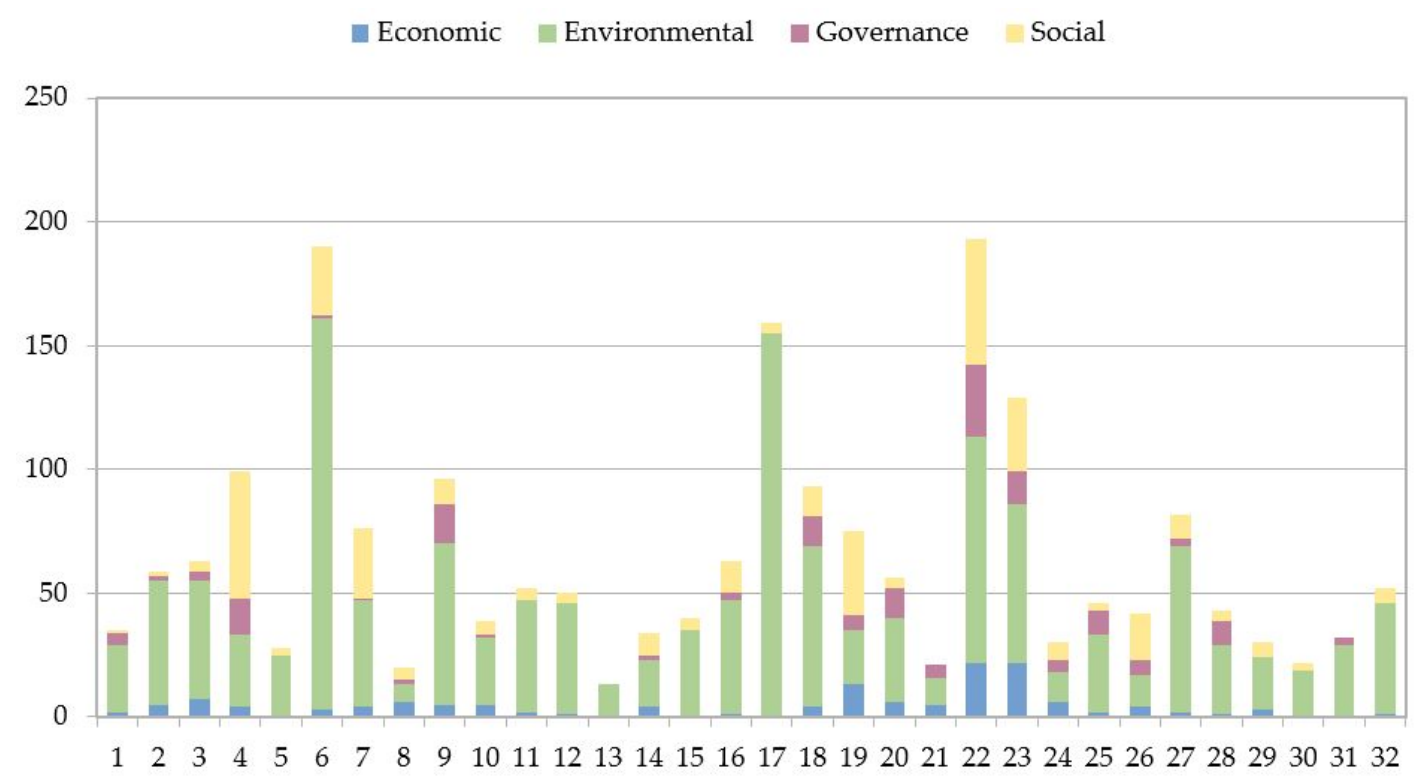

Figure 2. Distribution of considered aspects by framework.

\subsection{Environmental Aspects}

Environmental sustainability ensures fundamental needs such as the preservation and improvement of natural resources and the protection and restoration of environment and habitat. A sustainable environment implies that an ecosystem is able to maintain its functionality over time. The environmental sustainability proposed structure consists of seven categories, widely classified in two big groups, considering the area of action they fall into: Resources and Territory Management.

Figure 3 shows the distribution of environmental aspects considered by each analyzed framework, according to the proposed categories within this section: water, waste, site and land, pollution, plan and design, mobility and transport and energy.

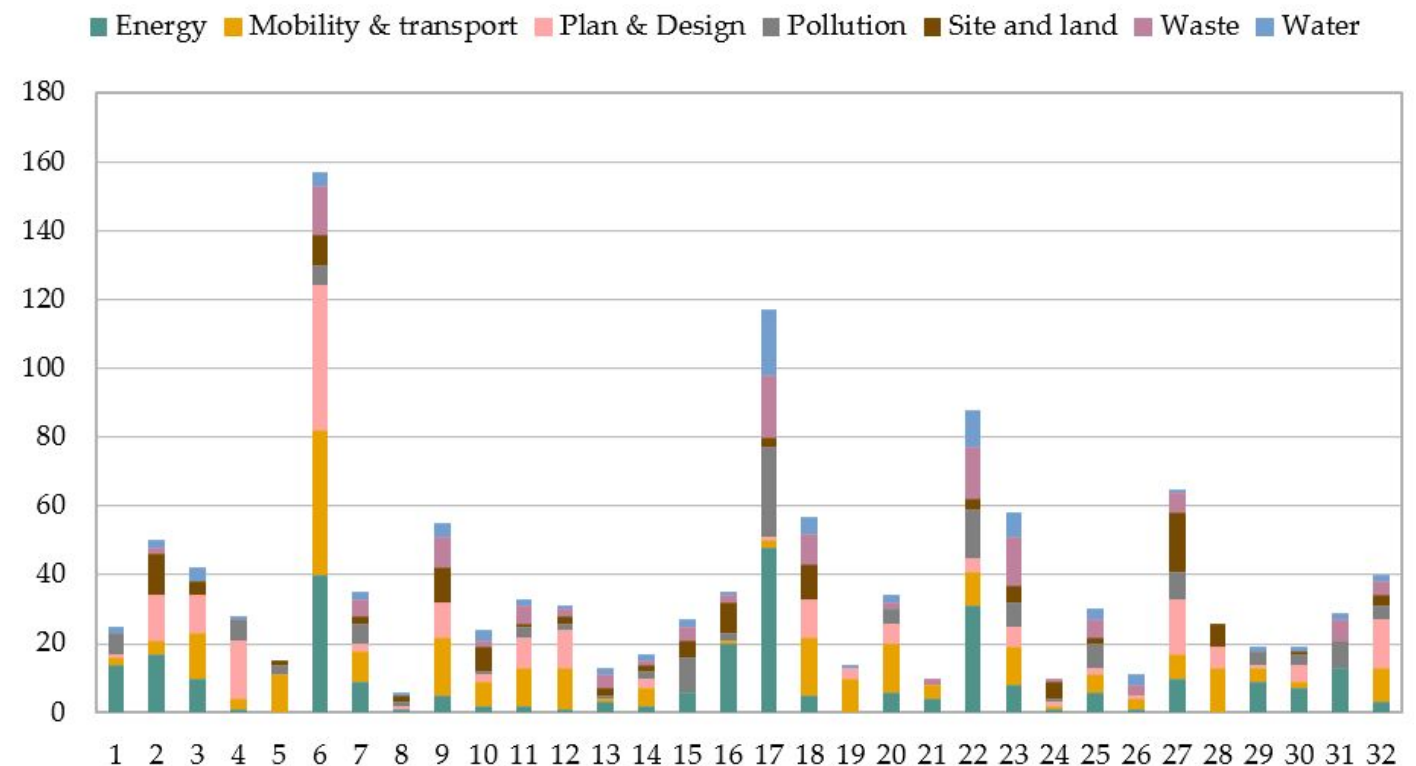

Figure 3. Distribution of environmental aspects considered by framework.

\subsubsection{Resources}

Resources include 4 categories-Energy, Waste, Water and Pollution (see Table 3). The four of them were present in more than half of the analyzed assessment tools (17/32) and at least 2 of these categories 
were present on every framework, which came as no surprise, as natural resources and pollution are some of the most concerning aspects of environment conservation.

Table 3. Proposed indicators for environmental aspects (resources area).

\begin{tabular}{|c|c|c|c|}
\hline Category & Subcategory & $\mathbf{N}$ & Indicator \\
\hline \multirow{8}{*}{ Energy } & Indoor environment quality & 1 & $\begin{array}{l}\text { Proportion of buildings certified by an } \\
\text { environmental quality sign }\end{array}$ \\
\hline & Consumption & 2 & Total energy consumption \\
\hline & \multirow[t]{2}{*}{ Efficiency } & 3 & $\begin{array}{l}\text { Proportion of energy self-sufficiency based on } \\
\text { renewable energies use }\end{array}$ \\
\hline & & 4 & Infrastructure and Buildings Energy Efficiency \\
\hline & Buildings & 5 & Housing density \\
\hline & \multirow{2}{*}{ Conservation } & 6 & Building age index \\
\hline & & 7 & Investment in restoration and conservation projects \\
\hline & Emissions & 8 & Greenhouse gases emissions \\
\hline \multirow{3}{*}{ Waste } & Waste water treatment & 9 & Use of systems to reuse/treat wastewater \\
\hline & Recycled/treated solid waste & 10 & Percentage of municipal solid waste recycled. \\
\hline & Waste management & 11 & Generation and waste management \\
\hline \multirow{3}{*}{ Water } & Access & 12 & $\begin{array}{l}\text { Percentage of population with sustainable access to } \\
\text { an improved water source }\end{array}$ \\
\hline & Efficiency & 13 & Efficiency of water usage \\
\hline & Consumption & 14 & Water consumption \\
\hline \multirow{4}{*}{ Pollution } & Light pollution & 15 & Reduce light pollution \\
\hline & Noise pollution & 16 & Reduce noise pollution \\
\hline & Gas pollution & 17 & Reduce gas pollution \\
\hline & Air quality & 18 & Improve air quality \\
\hline
\end{tabular}

Energy category represented almost a $25 \%$ of the environmental indicators object of study, which gives a good view of its importance when it comes to sustainability and the need for its proper representation in any assessment model [11].

Energy consumption and efficiency are two closely related concepts. Vast quantities of energy are consumed as economy [12] and people's expectations of comfort grow [13], which makes it vital to move towards more sufficient, renewable-based, pollutant-mitigating consumption policies [14].

Buildings constitute one of the main consumers of energy in cities, besides industry and transportation systems. It is important that buildings are constructed to be efficient and self-sufficient, according to their geographical situation [15] and use. As a result of this, a considerable number of certifications is available nowadays specifically for measuring sustainability of buildings based on those factors (use, location, etc.) [16].

Indoor environment quality (IEQ) involves many factors, as it refers to the quality of the interior spaces of a building in relation to the wellbeing of those that make use out of it. It includes aspects such as air quality, comfortable temperature, air quality and adequate humidity levels. Research has shown that IEQ has a relevant impact in the performance of those who occupy the space [17-19]. IEQ is a value that indicates to what extent the energy used for the construction and use of a building is useful or efficient.

Conservation is another key in urban sustainable development, as they are concepts that share common ground [20]. Successful architectural conservation and the adaptative reuse of heritage buildings to meet efficient resources management criteria could be beneficial [21], however it is a tricky subject, as it has been shown that despite its possible positive impact when it comes to sustainability, it could create certain issues [22].

All energy sources have certain impact on the environment; fossil fuels do substantially more harm than renewable energy sources by most measures, which makes it indispensable to promote aspects such as efficiency, self-sufficiency, percentage of renewable energies use and to reduce emissions [23]. 
Waste: the environmental effects of waste can be the cause of serious issues, both contributing to the greenhouse effect and affecting health. Gases coming from the incineration of waste may produce air pollution and contribute to acid rain if not treated properly [24]. Waste water is by definition the process that removes contaminants from waste water and sewage water so it can be returned to the water cycle or reused for certain purposes without a relevant impact on the environment $[25,26]$. Treatments may consist of chemical, biological or physical processes or even a combination of them and water can be treated to obtain any desired level of quality. However, the level of quality comes at a cost, hence the need to select appropriate outcome levels according to the future use of the treated water or its return back to the water cycle [27].

Water: population growth, the movement of large numbers of people to certain areas and the consequent high density of population in said areas, the demands for higher living standards, are some aspects that have affected the use of water resources. Once the basic need for water access [28] and water quality is accomplished, it is necessary to look into an efficient use of water resources $[29,30]$. Water consumption in urban areas is essential, hence being able to measure it becomes crucial. Different models for predicting urban water consumption have been developed during the past years, which can enable an improvement in the performance of water distribution systems [31]. This leads us to water efficiency, which should be approached both in households [32,33] and considering the whole urban water infrastructure [34].

Pollution: it is defined as "the contamination of the physical and biological components of the earth/atmosphere system to such an extent that normal environmental processes are adversely affected" and it may poison soils and waterways, lead to chronic diseases [35]. A holistic approach to resource management could be applied to start the way towards a solution of increasing worldwide pollution issues [36]. Even though gas pollution and air quality might be some of the most relevant and more studied factors within pollution, noise and light [37-39] pollution have been shown to be related to population wellbeing.

\subsubsection{Territory Management}

This area includes 3 categories-Mobility and Transport, Plan and Design and Site and Land (see Table 4).

Table 4. Proposed indicators for environmental aspects (territory management area).

\begin{tabular}{|c|c|c|c|}
\hline Category & Subcategory & $\mathbf{N}$ & Indicator \\
\hline \multirow{6}{*}{ Mobility \& transport } & Proximity to services & 19 & Distance to basic services \\
\hline & Traffic & 20 & $\begin{array}{l}\text { Surface of public road for automobile } \\
\text { traffic and public transport. }\end{array}$ \\
\hline & Accessibility & 21 & Accessibility to key services \\
\hline & Public transport & $\begin{array}{l}22 \\
23 \\
24\end{array}$ & $\begin{array}{l}\text { Access to public transport network } \\
\text { Quality of public transport network } \\
\text { Smart public transport network }\end{array}$ \\
\hline & Pedestrian-oriented urban structures & $\begin{array}{l}25 \\
26\end{array}$ & $\begin{array}{l}\text { Pedestrianized streets } \\
\text { Enlarged pedestrian } \\
\text { and pedestrian-priority areas }\end{array}$ \\
\hline & Cycling network availability & 27 & Quality cycling network \\
\hline \multirow{3}{*}{ Plan \& design } & Open/green areas & $\begin{array}{l}28 \\
29\end{array}$ & $\begin{array}{l}\text { Percentage of open/green public areas } \\
\text { Number of trees / Kilometer urban road }\end{array}$ \\
\hline & Roads & 30 & Length and surface or urban roads \\
\hline & Urban structure & 31 & $\begin{array}{l}\text { Pedestrian-oriented urban structures } \\
\text { with short distances }\end{array}$ \\
\hline \multirow{3}{*}{ Site and land } & Land use & 32 & Up-to-date sustainable land use \\
\hline & Conservation & 33 & $\begin{array}{l}\text { Maintain or re-cultivate/restore green } \\
\text { and water elements }\end{array}$ \\
\hline & Reuse & 34 & Prioritize the use of existing sites \\
\hline
\end{tabular}


Mobility and Transport: transport is an important factor in the context of sustainability, as generally it contributes highly to contamination and the greenhouse effect. An efficient transport system that provides smart, sustainable mobility structures is key for the health of both the environment and economy [40].

Accessibility and proximity to services have lately been considered as concepts of "walkable cities" or "15 minutes' city" [41]. Proximity to basic services has a wide range of positive impacts on the environment, from the reduction of vehicle emissions to the wellbeing of citizens [42]. Traffic management is another approach that can be taken to move towards sustainability in cities, which research that proposes different ways to achieve it [43].

ICT and sustainability connect to every service provided to communities in smart cities and play an important role in smart city planning, including in public transportation [44]. An efficient public network, with adequately positioned stops, can benefit largely from real-time information. An integrated cycling network availability that develops the concept of smart velomobility allows citizens to use an active, sustainable and intelligent way of transportation [45].

Pedestrian-oriented urban structures imply pedestrianized streets and enlarge pedestrian and pedestrian-priority areas, to improve the comfort citizens experiment in their walking environment, always considering aspects such as accessibility and safety, among others [46,47].

Plan and Design: environment can be integrated into urban planning, contemplating environmental priorities and strategies into development plans, promoting a smart mobility structure, a pedestrian-oriented urban structure and other aspects like the conservation and creation of public green areas [48,49].

Sustainable road network development should meet the usual sustainability criteria and reduces its impact on climate change, human health and biological diversity [50]. Concepts like "green roads" have been studied as an alternative for more sustainable civil engineering constructing practices [51].

Urban structure represents another factor that has been proven to affect city sustainability since it determines the location of pollution emission sources and traffic patterns [52], as well as it is related to mobility possibilities [53].

Site and Land: land use is closely related to Mobility and Transport and Plan and Design aspects. Changes in land use and the prioritization of the use of existing sites may reduce the need for transportation and hence reduce emissions [54]. Conservation of site implies the maintenance or recultivation/restoration of green and water elements of urban areas, which play an important role in citizen's sense of place with their environment [55,56].

The reuse land has become a strong policy aim in certain governments in their attempt for sustainable planning strategies $[57,58]$. The reuse of existing sites is also considered in the concepts of green urbanism [59].

\subsection{Social Aspects}

The third pillar of sustainability, its social aspect represents the contribution to a more equitable, diverse future. The social part of the overall sustainability index has received little attention compared to the previous aspects until recently [60], even though it provides the level of social sustainability performance and its areas of improvement, which would enhance a holistic better development and quality of life. Better social futures require anticipation, which could be obtained via relationally real structures [61,62].

The proposed social sustainability index consists of three sub-categories, which are housing, public spaces quality and health and wellbeing (see Table 5).

Housing and public quality: these two first sub-categories have been a concern historically and taken into account in City Planning since decades ago. Initially, the sole purpose of social housing was to overcome the need for shelter for socially vulnerable citizens. However, studies have shown that the low level of quality, which used to be common in this type of housing, had a negative impact 
both socially and environmentally which makes it important to consider these aspects in the planning approach to social housing [63,64].

Table 5. Proposed indicators for social aspects.

\begin{tabular}{cccc}
\hline Category & Subcategory & N & Indicator \\
\hline & Housing & 35 & $\begin{array}{c}\text { Proportion of social housing in } \\
\text { the neighborhood }\end{array}$ \\
\cline { 2 - 4 } Social aspects & Public spaces quality & 36 & $\begin{array}{c}\text { Integrate public spaces and streetscapes of } \\
\text { high spatial quality }\end{array}$ \\
\cline { 2 - 4 } & Health and wellbeing & 38 & $\begin{array}{c}\text { Access to basic services } \\
\text { Encouraging a healthy lifestyle } \\
\text { Ensuring healthy outdoor spaces }\end{array}$ \\
\hline
\end{tabular}

Accessibility to public greenspaces and open spaces of quality has been recommended as an indicator for public health [65]. The availability of these kind of spaces has proven to be beneficial not only for the environment but for citizen's wellness [66].

However, the concept of wellness and wellbeing is a growing concern that has been intensified in the past years, provoking a growing interest in processes that create places that promote wellbeing, resulting in the appearance of new assessment tools and certifications that focus on this sustainability aspect, like WELL certification. City livability is also closely related to the concept of urban wellbeing and to other environmental aspects mentioned before like urban pollution [67].

\subsection{Governance Aspects}

Governance helps implement sustainability strategies, manage goal-setting and reporting processes and ensure overall accountability. However, despite the fact that the relationship between sustainability and governance is fundamental in the development of the former, the work including governance in sustainability frameworks is still limited [68].

Governance indicators are key to ensure the functioning of the whole society and when used efficiently, informed by science, they can be a critical component of sustainable development. They are usually overseen and poorly included in indicator frameworks and assessments, which is incoherent, as public institutions should be leading the change towards a more sustainable territory, both through legislation and through actions. From Management to City Planning and even Innovation, every aspect matters and should be taken into account. Ultimately, indicators must reflect political reality, information availability and a relevant scale of analysis [69].

United Nations Development Program (UNDP) published "A Users' Guide to Measuring Local Governance" where they specified a total of 22 governance frameworks [70] which are adopted by various countries across the world in order to evaluate governance [71]. Since nowadays transparency should be part of every public organism, the contemplated data should be easily obtained. Governance indicators have been categorized in four categories based on their representation of a common goal, as follows (see Table 6).

Management: it is necessary to ensure objectivity during the process of diagnosing, decision making, drafting and approving urban plans and also while integrating Agenda 21 [72].

City Planning and innovation: the effects of urban planning indicators on the urban regime can provide useful tools to urban planners and policymakers for the evaluation of the impact of an urban transformation of the city at different scales: green areas and how they affect the intra-urban thermal regime [73] the availability and accessibility of public transport and so forth. Innovation positively evaluates the implementation of innovative solutions in different aspects of urban sustainability. Innovation is the key to progress, particularly in times of crisis [74]. 
Table 6. Proposed indicators for governance aspects.

\begin{tabular}{|c|c|c|c|}
\hline Category & Subcategory & $\mathbf{N}$ & Indicator \\
\hline \multirow{2}{*}{ Management } & $\begin{array}{l}\text { Monitoring } \\
\text { and reporting }\end{array}$ & 40 & $\begin{array}{l}\text { Implementation of monitoring } \\
\text { and reporting systems }\end{array}$ \\
\hline & Integrating agenda 21 & 41 & $\begin{array}{c}\text { Integration of Agenda } 21 \text { into } \\
\text { urban planning }\end{array}$ \\
\hline \multirow{2}{*}{$\begin{array}{l}\text { City planning } \\
\text { and innovation }\end{array}$} & \multirow{2}{*}{$\begin{array}{l}\text { Smart city policy } \\
\text { development }\end{array}$} & 42 & $\begin{array}{c}\text { Transition towards smart city } \\
\text { (implementation of sensors, open data, ... ) }\end{array}$ \\
\hline & & 43 & Citizens access to ICT information \\
\hline Transparency & Transparency & 44 & Transparency and open Government \\
\hline
\end{tabular}

Transparency: this aspect is often credited with generating government accountability, which would lead to reduction in government corruption, bribery and other malfeasance. However, even in democratic societies, public officials have incentives to pursue secrecy, as it provides fertile ground for special interests and undermines the ability to provide an effective check against the actions of government. It is fundamental for government to provide transparency in sustainability as in all matters, acting in the interest of citizens and their territory [68].

\subsection{Economic Aspects}

The economic pillar of sustainability implies understanding that the measures of unsustainability arising from a consumer led culture that treats finite resources as an income leads to an inevitable. This economic aspect is used to define strategies that promote de use of resources optimally, considering an equitable, efficient distribution of resources.

The number of proposed economic indicators in literature is almost endless, has economy has been historically studied to very large extents. However, if we take into account the 32 indicators sets considered in this article, economic aspects do not represent a high percentage (nearly $5 \%$ ) of the total of unified categories. The fact that the sets are mostly focused on environmental factors could explain this, as they contain principally basic economy indicators, while only a few of them go more in depth into economy issues. The economic sustainability index consists of three sub-categories, which are the local aspect of economy, labor and finances (see Table 7).

Table 7. Proposed indicators for economic aspects.

\begin{tabular}{cccc}
\hline Category & Subcategory & N & Indicator \\
\hline Local aspect & Local resources & 45 & Encourage use of local resources \\
\cline { 2 - 4 } & Labor and skills & 46 & $\begin{array}{c}\text { Strengths and local specifics of the labor } \\
\text { force including the availability of workers } \\
\text { with different qualifications }\end{array}$ \\
\hline Labor & Employment & 47 & Employment rate \\
\hline Finances & Household income & 48 & Average household income \\
\hline
\end{tabular}

Local resources: one of the objectives of sustainability is to establish local economies that are environmentally friendly, socially responsible and of course economically viable. The use of local resources would be in favor for those three aspects, considering it could enhance the creation of jobs locally, reduce emissions due to transportation and contribute to the area's economy [75].

Labor: as previously stated, climate change is sensitive to human activity but also that much of human activity is sensitive to climate change, hence the emergence of concepts such as green economy and economic sustainability [76]. 
Finances: average house income is present in most of economic indicator-based assessments, as it can be used as an indicator for the monetary well-being of a country's citizens. Low-income households are a matter of debate due to its possible consequences for sustainability [77].

Finally, in Figure 4 the developed structure has been graphically represented, which makes it easier to check visually the characteristics of a sustainable urban design at a glance. The graphic represents the proposed areas, categories and subcategories.

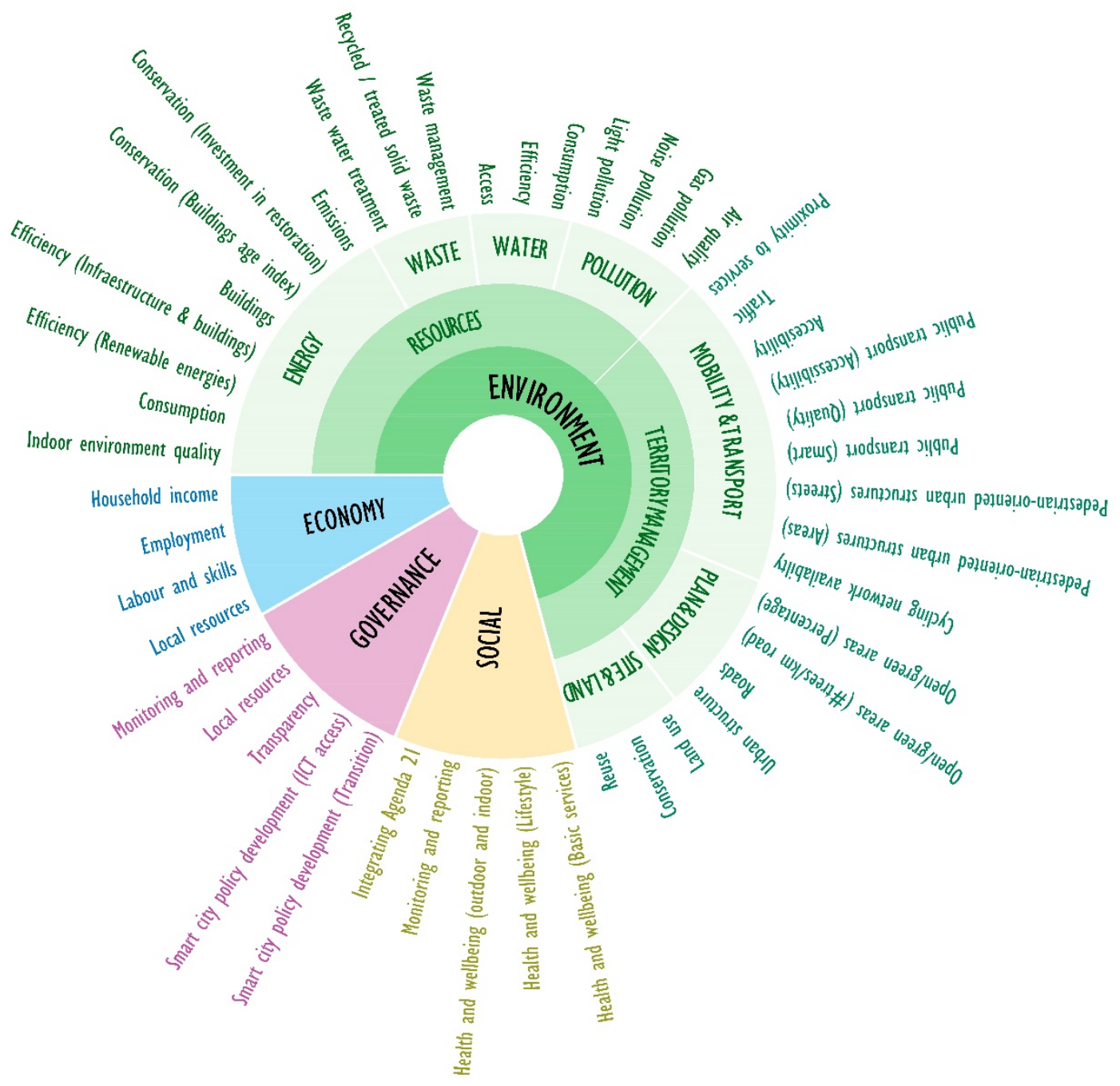

Figure 4. Proposed structure for areas, categories and subcategories.

\section{Discussion and Conclusions}

Sustainability has recently been object of study due to its impact on the planet and on human activity. Particularly urban environments are locations that represent a high percentage of emissions of gases, waste, energy and so forth. Numerous authors have developed tools for measuring the sustainability of buildings and urban environments to address this global challenge issue. The importance of assessment tools for the measure of sustainability in urban areas is clear, as they are a proven method for driving sustainable urban developed, which shows considering the increasing number of frameworks being developed in a short amount of time. However, while the pursued aim is often the same, the way to reach it varies from one to another and a common criterion has not yet been set in that sense, resulting in diverse, heterogeneous frameworks.

While some frameworks or guidelines offer a very wide range of almost 200 hundred indicators, it has not been proven that such a high number of information compensates the effort that it takes to 
obtain it. On the other hand, assessment tools with a very small number of indicators may result in poor overall information. It is then recommended to use enough indicators to get an overall view of the sustainability aspects of an urban area, without compromising its total cost.

The approaches may lie in certain aspects of the cities due to cultural and social characteristics or the great differences in terms of the level of development and industry, among others. Therefore, there are very specific tools for certain problems (such as City Blueprint), without a totally holistic solution.

This study proposes a response to this situation, considering 32 international frameworks and tools of diverse natures, resulting in a structure consisting of 14 categories (Energy, Waste, Water, Pollution; Mobility \& Transport, Plan \& Design, Site \& Land; Social aspects, Governance Management, City Planning \& Innovation, Transparency; Economy's Local Aspect, Labor and Finances) and 48 indicators.

This has been possible through a thorough review of the indicator's structures proposed in the existent literature and a frequency analysis for categories, subcategories and indicators of each tool selected for this study, supported by a cluster analysis used for the verification of the preciously made correlations.

The result provides a list of basic indicators that tries to fulfill all due aspects to obtain a general diagnosis of the sustainable nature of the urban environment, which can serve as support to detect the strongest and weakest areas in terms of their sustainability of the urban environment. Subsequently, other more specific existing tools such as those mentioned above could be applied to measure and improve said specific aspect.

The list of proposed indicators is not final, as it should evolve as knowledge and data availability improve and it is definitely arguable, as any attempt of proposal of a set of indicators would be, however similar the objectives could be. Ultimately, the list is expected to include key indicators for highly different yet interconnected issues such as resources and territory management and social, governance and economy factors.

Author Contributions: Conceptualization, A.L.C., A.C.G. and V.L.-C.; Data curation, A.L.C.; Formal analysis, A.L.C.; Methodology, A.L.C. and V.L.-C.; Software, A.L.C., V.L.-C. and A.A.; Supervision, A.C.G., V.L.-C. and A.A.; Visualization, V.L.-C.; Writing-original draft, A.L.C.; Writing-review \& editing, V.L.-C. and A.A. All authors have read and agreed to the published version of the manuscript.

Funding: This research received no external funding.

Conflicts of Interest: The authors declare no conflict of interest.

\section{References}

1. Seto, K.C.; Fragkias, M.; Güneralp, B.; Reilly, M.K. A Meta-Analysis of Global Urban Land Expansion. PLoS ONE 2011, 6, e23777. [CrossRef] [PubMed]

2. United Nations, Department of Economic and Social Affairs, Population Division. World Urbanization Prospects: The 2018 Revision; United Nations, Department of Economic and Social Affairs, Population Division: New York, NY, USA, 2016.

3. Wendling, L.A.; Huovila, A.; zu Castell-Rüdenhausen, M.; Hukkalainen, M.; Airaksinen, M. Benchmarking Nature-Based Solution and Smart City Assessment Schemes Against the Sustainable Development Goal Indicator Framework. Front. Environ. Sci. 2018, 6, 69. [CrossRef]

4. Garau, C.; Pavan, V. Evaluating Urban Quality: Indicators and Assessment Tools for Smart Sustainable Cities. Sustainability 2018, 10, 575. [CrossRef]

5. Brundtland, G.H. Our Common Future-Call for Action. Environ. Conserv. 1987, 14, 291-294. [CrossRef]

6. Kennedy, C.; Cuddihy, J.; Engel-Yan, J. The Changing Metabolism of Cities. J. Ind. Ecol. 2007, 11, 43-59. [CrossRef]

7. Kitchin, R.; Lauriault, T.P.; McArdle, G. Knowing and governing cities through urban indicators, city benchmarking and real-time dashboards. Reg. Stud. Reg. Sci. 2015, 2, 6-28. [CrossRef]

8. Bell, S.; Morse, S. Measuring Sustainability: Learning by Doing; Earthscan Publications Ltd.: London, UK, 2003; ISBN 978-1-85383-839-2. 
9. Purvis, B.; Mao, Y.; Robinson, D. Three pillars of sustainability: In search of conceptual origins. Sustain. Sci. 2019, 14, 681-695. [CrossRef]

10. López-Chao, V. El impacto del Diseño del Espacio y Otras Variables Socio-Físicas en el Proceso de Enseñanza-Aprendizaje. Ph.D. Thesis, Universidade da Coruña, A Coruña, Spain, 2017.

11. Grigoroudis, E.; Kouikoglou, V.S.; Phillis, Y.A.; Kanellos, F.D. Energy sustainability: A definition and assessment model. Oper. Res. Int. J. 2019. [CrossRef]

12. Apergis, N.; Payne, J.E. Energy consumption and economic growth: Evidence from the Commonwealth of Independent States. Energy Econ. 2009, 31, 641-647. [CrossRef]

13. Saint Akadiri, S.; Alola, A.A.; Akadiri, A.C.; Alola, U.V. Renewable energy consumption in EU-28 countries: Policy toward pollution mitigation and economic sustainability. Energy Policy 2019, 132, 803-810. [CrossRef]

14. Chappells, H.; Shove, E. Debating the future of comfort: Environmental sustainability, energy consumption and the indoor environment. Build. Res. Inf. 2005, 33, 32-40. [CrossRef]

15. Yılmaz, Z. Evaluation of energy efficient design strategies for different climatic zones: Comparison of thermal performance of buildings in temperate-humid and hot-dry climate. Energy Build. 2007, 39, 306-316. [CrossRef]

16. Berardi, U. Sustainability Assessment in the Construction Sector: Rating Systems and Rated Buildings: Sustainability Assessment in the Construction Sector. Sust. Dev. 2012, 20, 411-424. [CrossRef]

17. López-Chao, V.; Amado Lorenzo, A.; Martín-Gutiérrez, J. Architectural Indoor Analysis: A Holistic Approach to Understand the Relation of Higher Education Classrooms and Academic Performance. Sustainability 2019, 11, 6558. [CrossRef]

18. Baeza Moyano, D.; Fernández, M.S.J.; González Lezcano, R.A. Towards a Sustainable Indoor Lighting Design: Effects of Artificial Light on the Emotional State of Adolescents in the Classroom. Sustainability 2020, 12, 4263. [CrossRef]

19. López-Chao, V.; Amado Lorenzo, A.; Saorín, J.L.; de la Torre-Cantero, J.; Melián-Díaz, D. Classroom Indoor Environment Assessment through Architectural Analysis for the Design of Efficient Schools. Sustainability 2020, 12, 2020. [CrossRef]

20. Rodwell, D. Conservation and Sustainability in Historic Cities; Publishing House of Electronics Industry: Beijing, China, 2015; ISBN 9787121272561.

21. Ma, Z.; Cooper, P.; Daly, D.; Ledo, L. Existing building retrofits: Methodology and state-of-the-art. Energy Build. 2012, 55, 889-902. [CrossRef]

22. Bullen, P.A.; Love, P.E.D. Adaptive reuse of heritage buildings. Struct. Surv. 2011, 29, 411-421. [CrossRef]

23. Song, J.; Feng, Q.; Wang, X.; Fu, H.; Jiang, W.; Chen, B. Spatial Association and Effect Evaluation of $\mathrm{CO}_{2}$ Emission in the Chengdu-Chongqing Urban Agglomeration: Quantitative Evidence from Social Network. Anal. Sustain. 2018, 11, 1. [CrossRef]

24. Liu, M.; Woudstra, T.; Promes, E.J.O.; Restrepo, S.Y.G.; Aravind, P.V. System development and self-sustainability analysis for upgrading human waste to power. Energy 2014, 68, 377-384. [CrossRef]

25. Tchobanoglous, G.; Burton, F.L.; Stensel, H.D. Wastewater Engineering: Treatment and Reuse; McGraw-Hill series in civil and environmental engineering; McGraw-Hill: Boston, MA, USA, 2002; ISBN 978-0-07-124140-3.

26. Leslie, G.P.G., Jr.; Glen, T.D.; Nancy, G.L.; Carlos, D.M.F. Biological Wastewater Treatment, 3rd ed.; IWA Publishing: London, UK, 2011; ISBN 978-1-4200-0963-7.

27. Englande, A.J.; Krenkel, P.; Shamas, J. Wastewater Treatment \&Water Reclamation. In Reference Module in Earth Systems and Environmental Sciences; Elsevier: Amsterdam, The Netherlands, 2015; ISBN 978-0-12-409548-9.

28. Aiga, H.; Umenai, T. Standardisation of the definition of access to safe water. Lancet 2003, 361, 2156. [CrossRef]

29. Yang, W.; Hyndman, D.W.; Winkler, J.A.; Viña, A.; Deines, J.M.; Lupi, F.; Luo, L.; Li, Y.; Basso, B.; Zheng, C.; et al. Urban water sustainability: Framework and application. Ecol. Soc. 2016, 21, art4. [CrossRef]

30. Milman, A.; Short, A. Incorporating resilience into sustainability indicators: An example for the urban water sector. Glob. Environ. Chang. 2008, 18, 758-767. [CrossRef]

31. Cutore, P.; Campisano, A.; Kapelan, Z.; Modica, C.; Savic, D. Probabilistic prediction of urban water consumption using the SCEM-UA algorithm. Urban Water J. 2008, 5, 125-132. [CrossRef]

32. Lee, M.; Tansel, B.; Balbin, M. Urban Sustainability Incentives for Residential Water Conservation: Adoption of Multiple High Efficiency Appliances. Water Resour Manag. 2013, 27, 2531-2540. [CrossRef]

33. Lee, M.; Tansel, B.; Balbin, M. Influence of residential water use efficiency measures on household water demand: A four year longitudinal study. Resour. Conserv. Recycl. 2011, 56, 1-6. [CrossRef] 
34. Bell, S. Renegotiating urban water. Prog. Plan. 2015, 96, 1-28. [CrossRef]

35. Finco, A.; Nijkamp, P. Pathways to urban sustainability. J. Environ. Policy Plan. 2001, 3, 289-302. [CrossRef]

36. Niemczynowicz, J. New aspects of urban drainage and pollution reduction towards sustainability. Water Sci. Technol. 1994, 30, 269-277. [CrossRef]

37. Brunekreef, B.; Holgate, S.T. Air pollution and health. Lancet 2002, 360, 1233-1242. [CrossRef]

38. Goines, L.; Hagler, L. Noise Pollution: A Modem Plague. South Med. J. 2007, 100, 287-294. [CrossRef]

39. Chepesiuk, R. Missing the Dark: Health Effects of Light Pollution. Environ. Health Perspect. $2009,117$. [CrossRef] [PubMed]

40. Lopez-Carreiro, I.; Monzon, A. Evaluating sustainability and innovation of mobility patterns in Spanish cities. Analysis by size and urban typology. Sustain. Cities Soc. 2018, 38, 684-696. [CrossRef]

41. Marquet, O.; Miralles-Guasch, C. The Walkable city and the importance of the proximity environments for Barcelona's everyday mobility. Cities 2015, 42, 258-266. [CrossRef]

42. de Nazelle, A.; Morton, B.J.; Jerrett, M.; Crawford-Brown, D. Short trips: An opportunity for reducing mobile-source emissions? Transp. Res. Part D Transp. Environ. 2010, 15, 451-457. [CrossRef]

43. Boltze, M.; Tuan, V.A. Approaches to Achieve Sustainability in Traffic Management. Procedia Eng. 2016, 142, 205-212. [CrossRef]

44. Bifulco, F.; Tregua, M.; Amitrano, C.C.; D'Auria, A. ICT and sustainability in smart cities management. Int. J. Public Sect. Manag. 2016, 29, 132-147. [CrossRef]

45. Behrendt, F. Why cycling matters for Smart Cities. Internet of Bicycles for Intelligent Transport. J. Transp. Geograph. 2016, 56, 157-164. [CrossRef]

46. Forsyth, A.; Southworth, M. Cities Afoot-Pedestrians, Walkability and Urban Design. J. Urban Des. 2008, 13, 1-3. [CrossRef]

47. Ovstedal, L.; Ryeng, E.O. Who Is The Most Pleased Pedestrian? In Proceedings of the 3rd International Conference, Steps towards Liveable Cities, Donastia-San Sebastián, Spain, 8-11 May 2002.

48. Newman, P.W.G. Sustainability and cities: Extending the metabolism model. Landsc. Urban Plan. 1999, 44, 219-226. [CrossRef]

49. Yiftachel, O.; Hedgcock, D. Urban social sustainability. Cities 1993, 10, 139-157. [CrossRef]

50. Puodziukas, V.; Svarpliene, A.; Braga, A. Measures for Sustainable Development of Road Network. Transp. Res. Procedia 2016, 14, 965-972. [CrossRef]

51. Muench, S.T.; Anderson, J.; Bevan, T. Green Roads: A Sustainability Rating System for Roadways. Int. J. Pavement Res. Technol. 2010, 3, 270-279.

52. Borrego, C.; Martins, H.; Tchepel, O.; Salmim, L.; Monteiro, A.; Miranda, A.I. How urban structure can affect city sustainability from an air quality perspective. Environ. Model. Softw. 2006, 21, 461-467. [CrossRef]

53. Madlener, R.; Sunak, Y. Impacts of urbanization on urban structures and energy demand: What can we learn for urban energy planning and urbanization management? Sustain. Cities Soc. 2011, 1, 45-53. [CrossRef]

54. Pauleit, S.; Duhme, F. Assessing the environmental performance of land cover types for urban planning. Landsc. Urban Plan. 2000, 52, 1-20. [CrossRef]

55. Colley, K.; Craig, T. Natural places: Perceptions of wildness and attachment to local greenspace. J. Environ. Psychol. 2019, 61, 71-78. [CrossRef]

56. Carrus, G.; Lafortezza, R.; Colangelo, G.; Dentamaro, I.; Scopelliti, M.; Sanesi, G. Relations between naturalness and perceived restorativeness of different urban green spaces. Psyecology 2013, 4, 227-244. [CrossRef]

57. Williams, K.; Dair, C. A framework for assessing the sustainability of brownfield developments. J. Environ. Plan. Manag. 2007, 50, 23-40. [CrossRef]

58. Dair, C.M.; Williams, K. Sustainable Land Reuse: The Influence of Different Stakeholders in Achieving Sustainable Brownfield Developments in England. Environ. Plan. A 2006, 38, 1345-1366. [CrossRef]

59. Lehmann, S. Transforming the City for Sustainability: The Principles of Green Urbanism. J. Green Build. 2011, 6, 104-113. [CrossRef]

60. Baffoe, G.; Mutisya, E. Social sustainability: A review of indicators and empirical application. Environ. Manag. Sustain. Dev. 2015, 4. [CrossRef]

61. Hale, J.; Legun, K.; Campbell, H.; Carolan, M. Social sustainability indicators as performance. Geoforum 2019, 103, 47-55. [CrossRef] 
62. Popovic, T.; Barbosa-Póvoa, A.; Kraslawski, A.; Carvalho, A. Quantitative indicators for social sustainability assessment of supply chains. J. Clean. Prod. 2018, 180, 748-768. [CrossRef]

63. Petković-Grozdanović, N.; Stoiljković, B.; Shubenkov, M. Location Criteria Relevant for Sustainability of Social Housing Model. MATEC Web Conf. 2016, 73, 06001. [CrossRef]

64. Hall, M.; Purchase, D. Building or bodging? Attitudes to sustainability in UK public sector housing construction development. Sust. Dev. 2006, 14, 205-218. [CrossRef]

65. Annerstedt van den Bosch, M.; Mudu, P.; Uscila, V.; Barrdahl, M.; Kulinkina, A.; Staatsen, B.; Swart, W.; Kruize, H.; Zurlyte, I.; Egorov, A.I. Development of an urban green space indicator and the public health rationale. Scand. J. Public Health 2016, 44, 159-167. [CrossRef]

66. Lee, A.C.K.; Maheswaran, R. The health benefits of urban green spaces: A review of the evidence. J. Public Health 2011, 33, 212-222. [CrossRef]

67. del Mar Martínez-Bravo, M.; Martínez-del-Río, J.; Antolín-López, R. Trade-offs among urban sustainability, pollution and livability in European cities. J. Clean. Prod. 2019, 224, 651-660. [CrossRef]

68. Aras, G.; Crowther, D. Governance and sustainability: An investigation into the relationship between corporate governance and corporate sustainability. Manag. Decis. 2008, 46, 433-448. [CrossRef]

69. Kaufmann, D.; Kraay, A.; Zoido-Lobatón, P. Aggregating Governance Indicators. Policy Research Working Paper. Available online: https://info.worldbank.org/governance/wgi/pdf/govind.pdf (accessed on 2 May 2020).

70. Wilde, A.; Narang, S.; Laberge, M.; Moretto, L.; UNDP Oslo Governance Centre. A Users' Guide to Measuring Local Governance. Available online: https:/www.undp.org/content/dam/aplaws/publication/ en/publications/democratic-governance/dg-publications-for-website/a-users-guide-to-measuring-localgovernance-/LG\%20Guide.pdf (accessed on 24 March 2020).

71. Biswas, R.; Jana, A.; Arya, K.; Ramamritham, K. A good-governance framework for urban management. J. Urban Manag. 2019, 8, 225-236. [CrossRef]

72. Braulio-Gonzalo, M.; Bovea, M.D.; Ruá, M.J. Sustainability on the urban scale: Proposal of a structure of indicators for the Spanish context. Environ. Impact Assess. Rev. 2015, 53, 16-30. [CrossRef]

73. Petralli, M.; Massetti, L.; Brandani, G.; Orlandini, S. Urban planning indicators: Useful tools to measure the effect of urbanization and vegetation on summer air temperatures: Urban indicators and summer intra-urban air temperatures. Int. J. Climatol. 2014, 34, 1236-1244. [CrossRef]

74. Crielaard, J.P.; Omta, S. Innovation and sustainability: Create the innovative organisation. Eng. Bus. 2008, 1, 1-35.

75. Curtis, F. Eco-localism and sustainability. Ecol. Econ. 2003, 46, 83-102. [CrossRef]

76. Prinz, L.; Pegels, A. The role of labour power in sustainability transitions: Insights from comparative political economy on Germany's electricity transition. Energy Res. Soc. Sci. 2018, 41, 210-219. [CrossRef]

77. Lettenmeier, M.; Hirvilammi, T.; Laakso, S.; Lähteenoja, S.; Aalto, K. Material Footprint of Low-Income Households in Finland-Consequences for the Sustainability Debate. Sustainability 2012, 4, 1426-1447. [CrossRef]

Publisher's Note: MDPI stays neutral with regard to jurisdictional claims in published maps and institutional affiliations.

(C) 2020 by the authors. Licensee MDPI, Basel, Switzerland. This article is an open access article distributed under the terms and conditions of the Creative Commons Attribution (CC BY) license (http://creativecommons.org/licenses/by/4.0/). 